Journal of Agricultural Sciences
(Tarim Bilimleri Dergisi)

\title{
Current Status of Forage Crops Cultivation and Strategies for the Future in Turkey: A Review
}

\author{
Mustafa TAN $^{a}$ (D), Halil YOLCU ${ }^{b}$

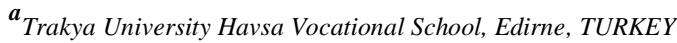

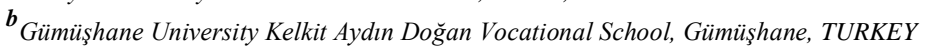 \\ ARTICLE INFO \\ Invited Review \\ Corresponding Author: Mustafa TAN, E-mail: mustafatan@trakya.edu.tr \\ Received: 26 March 2021 / Revised: 16 May 2021 / Accepted: 17 May 2021 / Online: 31 May 2021
}

\section{ABSTRACT}

Forage crops cultivation area in Turkey is 2.312 million ha in 2020. The rate of forage cultivation in the total agricultural area is $6.1 \%$, and its rate in the field land is $12.3 \%$. Lucerne, silage corn, oat, vetch, and sainfoin are main forage crops in Turkey. The amount of produced is 16.8 million tons of hay and 48.8 thousand tons of seeds. The forage crop cultivation areas have increased by $206 \%$ since the beginning of the 2000 s due to the government subsidies. However, shortage of quality roughage is still a big problem for animal husbandry of the country. For this reason, new strategies should be developed to increase forage cultivation areas by considering global warming, drought, and climate change. In order to meet the need for roughage, it is necessary to expand the cultivation area of forage crops as winter catch crops and second crops. In addition, some of the fallow fields should be utilized by growing drought-resistant forage species. The fields abandoned due to different problems should be used for the cultivation of suitable forage crops.

Keywords: Cultivation area, Hay and seed production, Organic production, New forage species, Animal husbandry

(C) Ankara University, Faculty of Agriculture

\section{Introduction}

Quality roughage is of great importance in feeding of livestock, since it ensures matching the nutrition requirements of animals for obtaining desired amounts of animal products such as milk, and meat. Rangelands, meadows and cultivated forage crop species in the arable lands are inevitable sources of quality roughage in Turkey (Sayar et al. 2010). In the mountainous regions where the winter season is harsh and long, the feed needed for feeding the livestock in the winter period is obtained from the forage crops cultivation areas and meadows. Therefore, for sustainable animal production, agricultural lands should be allocated for roughage production at a certain rate.

Besides using forage crop species for animal feeding, they are important for the agricultural ecosystem in many respects definitely oblige them to be included in different crop rotations systems (Acar et al. 2009). For instance, forage crops are sown more densely per unit area and harvested earlier than other product groups. In this way, they help the soil to rest and enrich its structure by leaving plenty of organic matter to the soil. Additionally, legume forage crops such as alfalfa, clover, and vetch fix the free nitrogen of the air to the soil and ensure that the next plants are more productive (Acikgoz 2001). Also, forage crops play an important role in reducing fallow lands, preventing soil and water erosion, and controlling diseases and pests (Tan 2018). Therefore, forage crops should be grown to improve soil conditions and control diseases and pests as well as produce forage.

Forage crop cultivation has been ongoing since the past because livestock is an important source of livelihood in Turkey. Moreover, forage cost constitutes 50-70\% of operating input costs in animal production (Anonymous 2019a). Lucerne (Medicago sativa L.), sainfoin (Onobrychis sativa Lam.), common vetch (Vicia sativa L.) and bitter vetch (Vicia ervilia (L.) Willd.) are grown in Anatolia since the Hittites (Tarman 1972). Although bitter vetch cultivation has decreased, other forage crop species such as forage pea, silage corn, faba bean, and grass pea have begun cultivation in the last two decades. In addition to these forages, new species such as Italian ryegrass, forage turnip, Hungarian vetch, clovers, and some meadow grasses are becoming widespread all over the country. The product variety and the cultivation areas of forage crops are increasing in Turkey due to the government subsidises the cultivation of forage crops for animal production. Despite this, it is not enough to meet the quality roughage requirement of animal existence. Insufficient roughage production in Turkey is one of the major problems of animal production. For this reason, in this period when the effects of global warming are beginning to be felt, it is of great importance to determine the current situation of forage crop cultivation areas and to observe the change in forage cultivation areas in recent years, and develop new strategies to increase forage cultivation. Therefore, this article reveals the current situation of forage crop 
cultivation areas within total agricultural areas in Turkey in 2020 and forages crop areas' change in recent years. In addition, with the help of this current data, the paper presents some approaches and new scenarios to solve the problems of forage cultivation by also considering global warming.

\section{Agricultural Areas Use in Turkey}

The agricultural area in Turkey is 37,753,000 ha in 2020 (Table 1, TUIK 2020). Meadow and rangeland areas are 14,617,000 ha, field crops cultivation areas are 18,788,000 ha and fruit and vegetable cultivation areas are 4,348,000 ha. The vast majority of crop cultivation lands are in dry farming areas and 3,173,000 ha of these areas left fallow every year. The ratio of fallow land to total agricultural land is $8.4 \%$. On the other hand, $13.7 \%$ of the cultivated agricultural areas (field + garden) are left fallow.

The forage crop cultivation area in Turkey's agricultural lands is 2,312,000 hectares. The share of this area in total agricultural land and field land is $6.1 \%$ and $12.3 \%$, respectively. The share of forage crops in total agricultural land was $2.9 \%$ in 2002 (Ozkan 2020) and 5\% in 2007 (Yolcu \& Tan 2008) in Turkey. Forage crop cultivation areas in Turkey have increased in the last two decades as a result of government subsidies, the shortage of quality roughage is however still a major problem for the country's livestock. Accordingly, many researchers emphasized that forage crops cultivation should be improved in order to minimise the deficit of quality roughage (Tan et al. 2002; Koc et al. 2012; Demiroglu Topcu \& Ozkan 2017; Acar et al. 2020). As a matter of fact, the rate of forage crop cultivation areas in Turkey is lower than in some countries such as Germany, France and Italy (Acikgoz et al. 2005; FAO 2019).

Table 1- Agricultural areas in Turkey (TUIK 2020)

\begin{tabular}{lcc}
\hline Agricultural Areas & Area (1,000 ha) & Ratio (\%) \\
\hline Cereal and other crops (Field area sown) & 15,615 & 41.4 \\
Fallow & 3,173 & 8.4 \\
Fruits, beverage and spice herbs & 3,564 & 9.4 \\
Vegetable gardens & 779 & 2.1 \\
Ornamental plants & 5 & 0.01 \\
Meadow-rangeland & 14,617 & 38.7 \\
\hline Total & 37,753 & 100 \\
\hline Forage Crops & 2,312 & $6.1 *$ \\
\hline
\end{tabular}

* This ratio is the ratio of the forage crops cultivation area to the total cultivated area. The ratio of forage crop cultivation area to field land is $12.3 \%$

\section{Forage Crops in Turkey}

Forage production in Turkey was conducted in 2,268,660 hectares which produced a total of 16,833,009 tons of hay (Table 2). Lucerne has the highest share in cultivation areas with 662,888 ha. Lucerne is followed by corn for silage (520,589 ha), oat for forage (324,018 ha), common vetch (224,386 ha) and sainfoin (174,494 ha) respectively. Other forage crops have low cultivation areas. Corn for silage has the highest total hay yield with $8,156,085$ tons in Turkey. It is followed by lucerne (4,822,630 tons), oat for forage (1,155,143 tons), common vetch (696,798 tons) and sainfoin (483,674 tons), respectively. Other forage crops have low total hay yields (Table 2). Corn for silage has the highest hay yield per unit area (15.67 tons ha $\left.{ }^{-1}\right)$. This followed by Italian grass $(11.51$ tons ha-1 $)$, sorghum (11.31 tons ha-1), forage turnip $\left(10.20\right.$ tons ha $\left.^{-1}\right)$ and lucerne $\left(7.28\right.$ tons ha $\left.^{-1}\right)$ respectively. Other forage crops have low hay yields per unit area (Table 2). 
Table 2- Cultivation areas, hay productions and yields of forage crops in Turkey (TUIK 2020)

\begin{tabular}{lrrr}
\hline Forage Crops & Cultivation Area $(\text { ha })^{l}$ & Total Hay Production $(\text { ton })^{2}$ & Hay Yield $\left(\right.$ t ha $\left.^{-1}\right)$ \\
\hline Lucerne & 662,888 & $4,822,630$ & 7.28 \\
Sainfoin & 174,494 & 483,674 & 2.77 \\
Common Vetch & 224,386 & 696,798 & 3.11 \\
Hungarian Vetch & 73,918 & 275,927 & 3.73 \\
Vetches (Other) & 77,639 & 163,015 & 2.10 \\
Forage Pea & 24,319 & 113,194 & 4.66 \\
Bitter Vetch & 2,294 & 3,641 & 1.59 \\
Grass Pea & 8,769 & 20,506 & 2.34 \\
Clover & 5 & 24 & 4.80 \\
Corn (Silage) & 520,589 & $8,156,085$ & 15.67 \\
Corn (for hay) & 5,672 & 37,843 & 6.67 \\
Sorghum & 2,332 & 26,376 & 11.31 \\
Italian Ryegrass & 25,329 & 291,507 & 11.51 \\
Oat & 324,018 & $1,155,143$ & 3.57 \\
Wheat & 17,866 & 104,651 & 5.86 \\
Barley & 31,319 & 161,120 & 5.14 \\
Rye & 6,851 & 29,459 & 4.30 \\
Triticale & 35,008 & 137,593 & 3.93 \\
Meadow Grasses & 44,637 & 97,949 & 2.19 \\
Fodder Beet & 1,670 & 8,376 & 5.02 \\
Forage Turnip & 4,657 & 47,498 & 10.20 \\
\hline Total & $2,268,660$ & $16,833,009$ & - \\
\hline
\end{tabular}

a, Seed production areas (41,628 ha) and dried faba bean for feed (1,384 ha) are not included. b, Hay productions are calculated from green material based on dry matter content of $30 \%$ in grasses, $25 \%$ in legumes, $20 \%$ in forage turnip and $10 \%$ in fodder beet.

Lucerne is the most cultivated in the Middle East Anatolia Region of Turkey (199,377 ha; Table 3). This is followed by the Northeastern Anatolia Region with 143,687 ha. The most cultivation regions of sainfoin are also Middle East Anatolia and Northeast Anatolia Regions (45,584 ha and 79,923 ha, respectively). It is noteworthy that lucerne and sainfoin cultivation areas are high in the eastern regions where animal husbandry is common and the winter period is long. Common vetch find more cultivation area in the Aegean and West Blacksea Regions (54,766 ha and 53,503 ha, respectively). These regions are followed by the Mediterranean region with 26,734 ha. $28.5 \%$ of silage corn cultivation areas $(148,604$ ha) is in the Aegean Region. West Marmara, East Marmara, West Anatolia, West Blacksea and Mediterranean regions are also the regions with the largest areas of corn for silage cultivation (Table 3).

Table 3- Regions of some forage crops cultivation for hay production in Turkey (TUIK 2020)

\begin{tabular}{lcccc}
\hline \multirow{2}{*}{ Statistical Regions } & \multicolumn{3}{c}{ Area (ha) } \\
\cline { 2 - 5 } & Lucerne & Sainfoin & Common Vetch & Silage Corn \\
\hline Mediterranean & 19,933 & 4,696 & 26,734 & 47,123 \\
West Anatolia & 46,465 & 2,519 & 9,558 & 54,064 \\
West Blacksea & 41,149 & 8,680 & 53,503 & 50,476 \\
West Marmara & 17,272 & 285 & 7,009 & 70,357 \\
East Blacksea & 9,388 & 4,525 & 3,457 & 1,716 \\
East Marmara & 36,254 & 1,634 & 11,246 & 60,802 \\
Aegean & 58,680 & 3,142 & 54,766 & 148,604 \\
Southeastern Anatolia & 14,915 & 1,208 & 15,018 & 32,028 \\
Northeast Anatolia & 143,687 & 79,923 & 13,953 & 13,091 \\
Middle Anatolia & 75,568 & 22,300 & 16,237 & 33,713 \\
Middle East Anatolia & 199,377 & 45,584 & 12,901 & 7,522 \\
Istanbul & 200 & - & 6 & 1,093 \\
\hline Total & 662,888 & 174,494 & 224,388 & 520,589 \\
\hline
\end{tabular}

Researches reveals that it has not met the necessary roughage requirement for livestock in Turkey. Acar et al. (2020) reported that $86,880,000$ tons of quality roughage was needed in the country, only $35.7 \%$ of this was met. Moreover, it was stated that the ratios of 29.8\% (Demiroglu Topcu \& Ozkan 2017) and 70.3\% (Ozkan 2020) of the necessary roughage were met in Turkey. Studies made in the last two decades shown that the country's roughage deficit has been continuing for a long time (Yolcu \& Tan 2008; Koc et al. 2012; Ozkan \& Sahin Demirbag 2016; Acar et al. 2020). The amount of hay produced from 2,268,660 ha forage crop cultivation area in Turkey is a total of 16,833,009 tones, according to recent data (Table 2). On the other hand, there are 18,614,990 bovines and 55,063,391 ovine (TUIK 2020). Roughage production has increased; but the animal number is also increasing. Therefore, the forage deficit still exists in Turkey, and these deficits are met by using field crop residues having low nutritive value. 


\section{Change of Forage Crops Cultivation Areas According to Years in Turkey}

Forage crops cultivation began to subsidy with 2000/467 Decree of The Ministry of Agriculture and Rural Affairs (About Decision Subsidy Livestock) in Turkey since 2000. The total forage cultivation area, which was 754,177 ha in 2000 , reached $2,311,167$ ha in 2020 with a substantial increase of $206 \%$ (Figure 1, TUIK 2020). The subsidy program for forage crop production is thought to be an important contribution for the increase in the production of forage crops after 2000 (Alas Eroglu et al. 2020). Lucerne cultivation areas, which were 250,800 hectares in 2000, reached 662,046 hectares in 2015 (Figure 1, TUIK 2020). However, no important increase was observed after 2015 for lucerne, sainfoin and vetch cultivation areas (Figure 1). On the other hand, there was an increase in silage corn, sorghum, Italian ryegrass and forage pea cultivation areas. The high yield potential of corn and the fact that sorghum and Italian ryegrass reached high yields by being harvested more than once a year in irrigated areas are the reasons why the cultivation of these plants has increases recently. There is a decrease in the cultivation areas of species such as fodder beet and forage turnips (TUIK 2020).

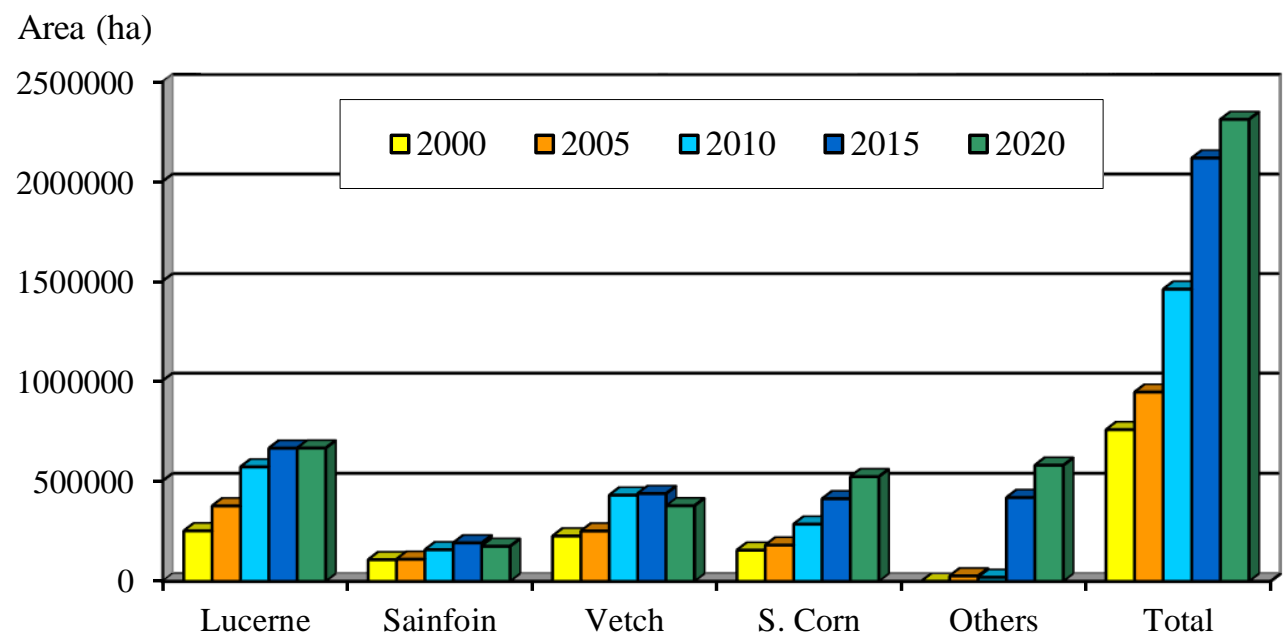

Figure 1- Changes of forage crops cultivation areas in Turkey, 2000-2020 period (TUIK 2020)

The cultivation area data of the small grain cereals as roughage is available since 2012 (Table 4). Although small grain cereals have some problems in terms of forage quality such as quick ripening and high lignin accumulation, they are an effective plant group in closing the roughage gap. The cultivation areas of small grain cereals for forage increase day by day due to the high adaptability, easy availability of seeds, and low labor requirements. Oat cultivation increased remarkably, especially after 2015. The fact that oat is a better roughage among small grain cereals, causes increase in its cultivation areas for hay.

Table 4- Cultivation areas of small grain cereals for forage in 2012-2020 in Turkey (TUIK 2020)

\begin{tabular}{cccccc}
\hline \multirow{2}{*}{ Years } & \multicolumn{5}{c}{ Area (ha) } \\
\cline { 2 - 6 } & Oat & Triticale & Wheat & Barley & Rye \\
\hline 2012 & 82,551 & 5,208 & 22,388 & 2,509 & 615 \\
2015 & 82,589 & 7,658 & 14,618 & 3,378 & 765 \\
2020 & 324,018 & 35,009 & 17,866 & 31,319 & 6,851 \\
\hline
\end{tabular}

\section{New Types of Forage Crops in Turkey}

Traditional forage plant species of Turkey's agriculture are lucerne, sainfoin, common vetch, and small grain cereals for forage. In addition to these, silage corn became widespread after 1980, and forage peas and fodder beet started to cultivate in the 2000s. In recent years, new forage crop species have started to be cultivated in Turkey. Some information about these species is given below.

Ryegrass (Lolium multiflorum L.): This type, which is a new plant for the agriculture of Turkey, has been grown in European countries for a long time. It is also known as Italian ryegrass or annual ryegrass in Europe, and it is recognized as milk grass in Turkey. This plant, which loves temperate climates, shows rapid and strong growth in a short time. It is usually grown alone or mixed with annual legumes to produce grass or to establish rotational pastures. It is also an ideal plant to conduct a short-term green area. Since it is an annual plant, it can easily find a place in crop rotation systems. In irrigation conditions with appropriate use of fertilizers, it gives more than one harvest and the hay yield rises above 10 ton ha ${ }^{-1}$ (Colak \& Sancak 2016; Turk et al. 2019). Data of ryegrass cultivation areas are available in Turkey since 2014. The cultivation area was 483 ha in 2014 , which reached 25,329 ha of cultivation area in 2020 (TUIK 2020). 
Forage Turnip (Brassica rapa L.): Turnip plants are generally grown to produce tubers to be used in human nutrition. However, plants in this group are also used in animal feeding. Forage turnips have a life span of one or two years. As well as the varieties are grown for their tubers, there are also varieties that do not produce tubers and whose only above ground parts are used for animal feeding. There are many types of forage turnips registered in Turkey. These types have a delicious and succulent plant structure with a high green biomass yield as a forage plant. Animals consume as green forage as well as silage. Cultivation areas were 4,657 hectares in Turkey recently (TUIK 2020).

Hungarian Vetch (Vicia pannonica Crantz.): Hungarian vetch cultivation in Turkey began in the early 2000s. Its cultivation area is 73,918 ha and the seed cultivation area is 7,912 ha in Turkey. One of the most important advantages of Hungarian vetch is sowing in winter months in the Middle and Eastern Regions of Turkey. It can be grown as an alternative to common vetch in regions with cold winters due to its resistance to cold. Its resistance to drought is also high. Hungarian vetch is used as a roughage, but it is not suitable for use as a grain feed due to its small grains. The most important problem of Hungarian vetch cultivation is its excessive characteristic to lie down and the difficulty of seed production. For this reason, there is a shortage of seeds in the sowing season.

Other Species: Clovers (Trifolium sp.) with 5-6 ha of cultivation areas is one of the other species. The genus of clover includes about 300 species growing in the world. Some of them are used for animal feeding by mowing or grazing. The most important plant of this group, the red clover (Trifolium pratense L.), has been cultivated in the Eastern Anatolia Region like lucerne, but today its cultivation areas have come to the point of disappearing. In recent years, annual clovers have been grown in Turkey's agricultural lands. These cultivation areas are commonly spread around Bursa province.

Data of meadow grasses have been available in Turkey since 2020 as a new forage crop group. In this group, there are mostly grass forage plant species. The cultivation areas of these plants, which are also used in the establishment of artificial pastures, were 44,637 ha (TUIK 2020).

In addition to the new forage plant species grown in Turkey, there are also potential species suitable for cultivation. High yield potential elephant grass (Miscanthus x giganteus; Ozdogan \& Geren 2019), different buckwheat types (Fagophyrum esulentum Moench., Kara \& Yuksel 2014), heat-resistant summer grass (Eragrostis teff [Zucc.] Trotter.) and quinoa for salty soils (Chenopodium quinoa Willd., Tan \& Temel 2018) are some of them. These species should be used for forage production in problem soils.

\section{Organic Forage Crops Cultivation in Turkey}

According to the data of the Ministry of Agriculture and Forestry for 2019, organic lucerne, organic sainfoin, organic vetch, organic forage pea, organic grass pea, and organic Hungarian vetch are cultivated as organic legumes forage crops in Turkey (Table 5; Anonymous 2019b). Corn for silage, Italian ryegrass, and millet were cultivated as organic forage grasses in Turkey. Meadow grass, forage turnip (hay), artificial meadow-rangeland, and fodder beet were cultivated as organic other forages (Table 5; Anonymous 2019b).

Table 5- Total hay yields of organic forage crops in Turkey (Anonymous 2019b)

\begin{tabular}{lr}
\hline Organic Forage Legumes & Hay Production (ton) \\
\hline Lucerne & $108,911.6$ \\
Sainfoin & $59,202.5$ \\
Vetch & $47,744.0$ \\
Forage Pea & 560.9 \\
Grass Pea & 286.3 \\
Hungarian Vetch & 237.8 \\
Bitter Vetch & 140.5 \\
\hline Organic Forage Grasses & \\
\hline Corn (For silage) & $6,527.8$ \\
Italian Ryegrass & 742.8 \\
Millet/Sorghum & 214.5 \\
\hline Organic Other Forages & $32,723.1$ \\
\hline Meadow Grass & 406.5 \\
Forage Turnip (Hay) & 259.8 \\
Meadow-Rangeland (Artificial) & 21.6 \\
Fodder Beet
\end{tabular}

The fact that some areas of organic forage production in Turkey are away from the organic livestock areas and organic rangeland which is the cheapest source of organic forage is not available are the most important problems of Turkey organic livestock (Yolcu et al. 2014). It is very important to make organic forage crop production near organic livestock areas and organic livestock based on organic meadows and pastures in terms of economical organic meat and milk production. 


\section{Grain Feeds in Turkey}

Grain or concentrate feeds are rich in terms of energy and protein content, and their digestion rate by animals is very high. Forage crop seeds are important concentrate feedstuffs. Exclusively corn, barley, oats, rye, triticale, sorghum, faba bean, common vetch, and bitter vetch species are grown for their grains in Turkey. Corn is the most grown and used grain feeds all over the world. Turkey produces 6 million tons of annual grain corn. But 7.8 million tons of grain corn are used domestically, 75\% of this amount is used in concentrate feed sector (Anonymous 2020). Turkey's corn production is not sufficient for the domestic market, it has imported 1.5-2 million tons of corn each year (Anonymous 2019a). According to Basbag et al. (2021) ground corn seed was found superior than the other concentrate feedstuffs in terms of feed quality parameters. Wheat is used very little as a grain feed. Oats and barley whose seeds are covered with husk are more commonly used as grain feeds. Barley is one of the grain feeds mostly used by producers in animal feeding because of its cheapness and abundance. Rye is grown as grain feed in arid and infertile soils. The cultivation of triticale is widespread especially in Eastern Anatolia due to its high yield and durability as grain feed.

In the Aegean and Mediterranean Regions, faba bean is commonly cultivated as a grain legume feed. On the other hand, forage pea is grown as a grain feed in the Eastern Anatolia Region, and bitter vetch is cultivated in the Middle Anatolia, Mediterranean, and Southeastern Anatolia regions as a grain feed. Cultivation as a grain feed of common vetch spreads in all regions of Turkey. Forage pea is grown as a grain feed in all regions of Turkey recently, due to the newly developed forage pea varieties. Narbon vetch to be grown for winter in Middle Anatolia conditions also has a great potential as grain feed (Uzunmehmetoglu \& Kendir 2006). Legume group grain feeds are important as the protein source of the rations. In addition, the seeds of some species in this group are used in poultry feeding.

Another importance of grain feeds is that they constitute the most important raw material for the concentrate feed industry. The concentrate feed industry uses cereals, oilseeds, and their by-products such as bran and pulps. Corn is mostly used as the raw material of concentrate feeds. Significant amounts of imports are also made in corn, feed oilseeds, and soybean for animal feed and soybean pulp is the leading one (Anonymous 2019a). The enhancement of feed grains cultivation as raw materials for the feed industry in addition to increasing the forage production in Turkey is of great importance for the development of the livestock sector.

\section{Forage Crops Seed Production in Turkey}

Lucerne, sainfoin, common vetch, Hungarian vetch, and other vetches are cultivated in order to get seeds in Turkey (Table 6). Lucerne in 2,885 ha, sainfoin in 452 ha, common vetch in 27,740 ha, and Hungarian vetch in 7,912 ha for seed production are cultivated in Turkey (TUIK 2020). Total seed production area is 41,628 ha that produced 48,799 tons of seeds.

Table 6- Forage crops areas sown for seed, seed production, and seed yields (TUIK 2020)

\begin{tabular}{lccc}
\hline Species & Area $($ ha $)$ & Seed Production $($ ton $)$ & Yield $\left(t\right.$ ha $\left.^{-1}\right)$ \\
\hline Lucerne & 2,885 & 1,695 & 0.58 \\
Sainfoin & 452 & 248 & 0.55 \\
Common Vetch & 27,740 & 33,031 & 1.19 \\
Hungarian Vetch & 7,912 & 10,158 & 1.28 \\
Vetches (Other) & 2,638 & 3,667 & 1.39 \\
\hline Total & 41,628 & 48,799 & - \\
\hline
\end{tabular}

Many crops for seed production are mostly cultivated in Western and Middle Anatolia Regions. The highest lucerne for seed production is cultivated in Middle Anatolia, Southeastern Anatolia and Western Anatolia Regions as 1,394 ha, 984 ha, and 260 ha, respectively. Almost all of the sainfoin seed cultivation (450 ha) is in Western Anatolia. Seed production of common vetch spread throughout the country. There are 15,022 ha of vetch cultivation areas for seed production in the Western Blacksea, 4,259 ha in Middle Anatolia, 3,543 ha in Western Anatolia, 1,769 ha in Southeastern Anatolia, and 1,653 ha in the Aegean Region (TUIK 2020).

The amount of seed produced in Turkey is not enough to meet the needs of the domestic market. According to the Records of the Ministry of Agriculture and Forestry, 2,269 tons of forage plant seeds and 7,089 tons of grass and meadow grass seeds were imported, and 519 tons of forage crops and 209 tons of grass-meadow grass were exported in 2019 (Anonymous $2019 \mathrm{c}$ ). 


\section{Scenarios and Strategies in Forage Crops Cultivation of Turkey}

Forage crops are cultivated in 2,268,660 ha that produced a total of 16,833,009 tons of hay from the field (Table 2). However, the calculations show that total roughage production together with the hay produced from meadows and pastures are not enough to meet the requirements of the animal existence. Therefore, ways to increase both hay and grain feed production should be investigated. Agricultural supports for forage crop cultivation have made a great contribution to the increase in cultivation areas of the forage since the early 2000s. However, data show that the increase in cultivation areas of important species such as lucerne, sainfoin, and vetch slowed down after 2015. Therefore, new subsidy programs are needed. The basin and product-based subsidy should be brought to the fore instead of the subsidy made according to the cultivation areas.

Forage crops share in total agricultural land in Turkey is $6.1 \%$. This share is $12.3 \%$ in the total field areas (Table 1). This share is not sufficient to meet the forage requirement of total animal existence and there are some difficulties to increase this share much higher. Food prices are increasing as a result of the increasing demand for food products worldwide. This situation causes producers to cultivate strategic products such as wheat, corn, rice, and potatoes that are directly consumed as human food. Moreover, there are difficulties in increasing forage crop farming in irrigated areas, due to the globally increasing drought risk. Rainfed agriculture is obligatory in most of Turkey's agricultural lands. It is inevitable that forage crop cultivation areas will be shifted to rainfed areas from irrigated agriculture areas. Forages that need less water such as sainfoin, vetch, smooth bromegrass, and sorghums should be cultivated in dry farming areas of Turkey.

It is left to 3,173,000 ha area of fallow in Turkey each year. Since it is not possible to remove the fallow completely without irrigation in agricultural systems, but it is possible to reduce fallow areas by cultivating drought-resistant forage plants in the fallow areas (Kusvuran et al. 2011). In addition, reduced and minimum tillage methods in rainfed agricultural areas should be used as soon as possible to produce forage. Winter forages and winter cereals for forage should be cultivated to take advantage of rain and snow water against the drought risk in this season. While lucerne and corn for silage are cultivated in irrigated areas in the summer season, triticale, Hungarian vetch, and forage peas should be sown as winter in rainfed areas. Besides, efforts should be made to develop cold-resistant varieties for winter.

Forage crops cultivation as both second crops and catch crops should be increased so that forage crops cultivation are more involved in crop rotation systems. Growing forage crops in the early years of orchard facilities can contribute to roughage production (Hatipoglu et al. 2020).

The problem of seeds in forage crops and of the insufficient number of forage varieties are still not solved in Turkey. The development of drought and cold resistant varieties should be focused on, and new varieties should be distributed all over the country. In response to the adaptation problem of foreign seeds, new varieties should be developed from local gene sources or hybrid seeds. New variety development programs should be implemented mainly for sainfoin. Developed sainfoin varieties should be produced in high amounts with the contracted farmer model, and should be distributed across the country. It is required to increase grain feed crops cultivation area for animal husbandry. The products needed by the feed industry should be supplied domestically. It should be ensured that soybean agriculture, which is imported from a foreign market to a large extent, becomes widespread in Turkey. Seed productions of grain corn, soybean, cereal for forage, and annual legumes (such as vetch, faba bean and forage pea) should be subsidized on a basin basis. The use of straw and field crop residues as roughage will continue from now on as before. These are one of the remedies to close the roughage gap. However, the producers should be made aware of the use of straw in feed rations rather than using it alone. Any alternative material with feed value other than cereal straw should be utilized. It should be ensured that legume straw, beet leaf, beet pulp, fruit pulp, and similar wastes are used for feeding animals.

\section{Conclusions}

Forage crop cultivation has made great improvements in the last two decades in Turkey. The forage crops cultivation area in Turkey is $2,312,000$ ha in 2020. The rate of this area in the total agricultural area is $6.1 \%$, and its rate in the field land is $12.3 \%$. However, the amount of produced forage is not sufficient to meet the needs of animal husbandry. Forage crops cultivation areas should be increased not only as the main product but also as the catch crop or second crop. Moreover, it should be also focused on the implementation of measures that provide more crops per unit area due to possible difficulties in further increasing the cultivation areas. Furthermore, in a part of 3,173,000 ha of fallow land, drought-resistant forage species should be grown to increase forage production. The increases in forage production can reduce the pressure on the rangelands as well as increase animal production and help protect natural resources. The development of forage crop farming will also contribute to the solution of erosion, inefficiency, disease, pest, and weed problems. In addition, forage crop farming should continue to be subsidized by the government. However, this subsidy should be done according to the amount of product, not the cultivation area. Special subsidy policies are needed to expand cultivation areas of drought-resistant forage crops and to increase their seed production and grain feed productions. 


\section{References}

Acar Z, Ayan I \& Gunaydın G (2009). Crop Rotation. OMU Faculty of Agriculture Textbook (In Turkish) No: 62.2

Acar Z, Tan M, Ayan I, Ugur O, Basaran U, Can E \& Kaymak G (2020). Status and development possibilities of forage crops cultivation in Turkey. Turkey Agricultural Engineering IX. Technical Congress Proceedings Book (In Turkish), Ankara, pp. 529-553.

Acikgoz E (2001). Forage Crops (In Turkish). Uludă̆ University Improvement Foundation Publication No: 182. Vipaş Inc. Com. Publication No: 58, Bursa, $584 \mathrm{p}$

Acikgoz E, Hatipoglu R, Altınok S, Sancak C, Tan A \& Uraz D (2005). Forage production and problems (In Turkish). Turkey Agricultural Engineering VI. Technical Congress, January 3-7, 2005, Ankara, pp: 503-518

Alas Eroglu N, Bozoglu M \& Bilgic A (2020). The impact of livestock supports on production and income of the beef cattle farms: A case of Samsun province, Turkey. Journal of Agricultural Sciences 26(1): 117-129

Anonymous (2019a). Mixed Feed Industry Report-2019. Turkey Feed Industry Association. Poyraz Ofset Printing, Ankara, $64 \mathrm{p}$

Anonymous (2019b). Republic of Turkey Ministry of Agriculture and Forestry, 2019 Organic Farming Statistics

Anonymous (2019c). Seeds in 2019 Sector Report. Ministry of Agriculture and Forestry, General Directorate of Agricultural Enterprises, Ankara

Anonymous (2020). Corn Report 2020. TMMOB the Chamber of Agricultural Engineers, April 3, 2020, Ankara

Basbag M, Sayar M S, Cacan E \& Karan H (2021). Determining quality traits of some concentrate feedstuffs and assessments on relations between the feeds and the traits using biplot analysis. Fresenius Environmental Bulletin 30(2A): 1627-1635

Colak E \& Sancak C (2016). The effects of different nitrogen fertilizer doses on yield and some agricultural traits of Italian ryegrass (Lolium italicum L.) cultivars (In Turkish). Journal of Field Crops Central Research Institute 25(1): 58-66 DOI: 10.21566/tbmaed.55211

Demiroglu Topcu G \& Ozkan Ş S (2017). General view to meadow-rangelands and forage crops cultivation of Aegean Region and Turkey (In Turkish). COMU Journal of Agriculture Faculty 5 (1): 21-28

FAO (2019). Food and Agricultural Organization, http://www.fao.org (Access date: 15.03.2021)

Hatipoglu R, Serbester U, Avc1 M \& Dönmez B (2020). Present status and development possibilities of forage production in Adana province (In Turkish). Turkish Journal of Agriculture-Food Science and Technology 8 (7): 1497-1501 DOI: 10.24925/turjaf.v8i7.1497

Kara N \& Yuksel O (2014). Can we use buckwheat as animal feed? (In Turkish) Turkish Journal of Agricultural and Natural Sciences 1(3): 295-300

Koc A, Tan M \& Erkovan H I (2012). An overview of fodder resources and animal production in Turkey. New Approaches for grassland research in a context of climate and socio-economic changes. Ciheam Mediterranean Seminars No: 102, October 3-6, 2012, Samsun, Turkey, pp. 15-22

Kusvuran A, Nazlı R I \& Tans1 V (2011). Current situation of meadow-rangelands, animal existence and cultivation for forage crops in Turkey and East Black Sea Region (In Turkish). Journal of Agricultural Faculty of Gaziosmanpasa University 28(2): 21-32

Ozdogan T \& Geren H (2019). A preliminary study on the effect of different nitrogen levels on the biomass yield and some yield characteristics of elephantgrass (Miscanthus x giganteus) used as an energy crops (In Turkish). Journal of Ege University Faculty of Agriculture 56(2): 257- 262 DOI: 10.20289/zfdergi.481848

Ozkan U (2020). Comparative overview and evaluation of Turkey's forage crops agriculture (In Turkish). Turkish Journal of Agricultural Engineering Research 1(1): 29-43

Ozkan U \& Sahin Demirbag N (2016). Status quo of quality roughage resources in Turkey (In Turkish). Turkish Journal of Scientific Reviews 9(1): 23-27

Sayar MS, Anlarsal AE \& Basbag M (2010). Current situation, problems and solutions for cultivation of forage crops in the Southeastern Anatolian Region (In Turkish). Harran Journal of Agricultural and Food Science 14: 59-67

Tan M (2018). Legume and Grass Forage Crops (In Turkish). Ataturk University Faculty of Agriculture Textbook No: 256, Erzurum, $356 \mathrm{p}$

Tan M \& Temel S (2018). Performance of some quinoa (Chenopodium quinoa Willd.) genotypes grown in different climate conditions. Turkish Journal of Field Crops 23(2): 180-186 DOI: 10.17557/tjfc.485617

Tan E, Avcioglu R, Munzur M \& Demiroglu G (2002). Grassland and forage crop cultivation in Turkish agriculture. Anadolu, Journal of AARI 12(2): 100-109

Tarman O (1972). Forage Crops, Meadow-Pasture Culture (In Turkish). Ankara University Faculty of Agriculture Publications No: 464, Textbook No: 157, Ankara

TUIK (2020). Crop production statistics. Data Portal for Turkey Statistics, Retrieved in 15, March, 2021 https://data.tuik.gov.tr/Kategori/GetKategori?p=tarim-111\&dil=1 (Access date: 15.03.2021)

Turk M, Pak M \& Bicakci E (2019). The effects of different nitrogen fertilizer doses on the yield and quality of some annual ryegrass (Lolium multiflorum L.) cultivars (In Turkish). Journal of Isparta Applied Sciences University Faculty of Agriculture 14(2): 219-225.

Uzunmehmetoglu B \& Kendir H (2006). Effects of winter and spring sowings on grain yields of narbon vetch (Vicia narbonensis L.) (In Turkish). Journal of Agricultural Sciences 12(3): 294-300. DOI: 10.1501/Tarimbil_0000000457

Yolcu H \& Tan M (2008). General view to Turkey forage crops cultivation (In Turkish). Journal of Agricultural Sciences 14(3): 303-312. DOI:10.1501/Tarimbil_0000001045

Yolcu H, Okcu M \& Tan M (2014). Current situation of organic roughage production in Turkey (In Turkish). Yuzuncu Yil University Journal of Agricultural Sciences 24: 201-209

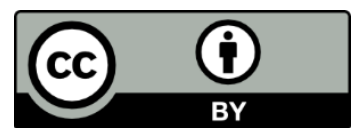

(C) 2021 by the authors. Licensee Ankara University, Faculty of Agriculture, Ankara, Turkey. This article is an open access article distributed under the terms and conditions of the Creative Commons Attribution (CC BY) license (http://creativecommons.org/licenses/by/4.0/). 